\title{
Alt veya Üst Ekstremite Ampute Simulasyonunun Serbest Yüzme Performansı Üzerine Etkisi: Ön Çalışma
}

\author{
The Effects of Upper or Lower Limb Amputee Simulation on Front \\ Crawl Swimming Performance: Preliminary Study
}

\author{
Nejla GERÇEK ${ }^{*}$ \\ Yaşar TATAR ${ }^{* *}$ \\ Selda UZUN ${ }^{* * *}$ iD
}

Öz

Bu çalışmanın amacı, alt veya üst ekstremite ampute simulasyonunun serbest yüzme sırasında üretilen ilerletici kuvvete etkisinin incelenmesidir. Çalışmaya 15-25 yaş aralığında 11 sağlıklı yüzücü dahil edilmiştir. Yüzücülerin tek kolları veya tek bacakları bağlanarak ampute simulasyonu oluşturulmuştur. Yüzücülerden üç farklı yüzme koşulunda (normal serbest yüzme, kol ampute simulasyonuyla ve bacak ampute simulasyonuyla serbest yüzme) 10 saniye boyunca maksimum hızda yüzmeleri istenmiştir. İpe bağlı yüzme sistemiyle elde edilen zirve kuvvet, ortalama zirve kuvvet ve impuls değerleri incelenmiştir. Normal, kol amputasyonunun simule edildiği ve bacak amputasyonunun simule edildiği serbest yüzme sirasında oluşturulan zirve kuvvet, ortalama zirve kuvvet ve impuls değerleri karşılaştırıldığında istatistiksel olarak anlamlı fark bulunmuştur $(\mathrm{p}<0,05)$. Kol ve bacak amputasyonun simule edildiği koşullar karşılaştırıldığında ise, sadece impuls değerlerinde anlamlı fark bulunmuştur $(\mathrm{p}<0,05)$. Kol veya bacak ampute simulasyonunun yüzme sırasında oluşturulan ilerletici kuvvet üzerinde negative etkisinin olması, ampute yüzücülerin sağlıklı akranlarına göre serbest yüzme sırasında dezavantajlı olduklarını göstermektedir. Kol ampute simulasyonuyla yüzme sırasında oluşturulan impuls bacak ampute simulasyonuyla oluşturulana göre daha fazla azaltmıştır. Bu sonuçlar, Uluslararası Paralimpik Komitenin tek dirsek üstü ampute ve tek diz seviyesi ampute olan yüzücülerin farklı yüzme sınıflarında yarışması gerektiği kararını desteklemektedir. Yüzme sırasında oluşturulan ilerletici kuvvetlerin ölçülmesi, engelli yüzücülerin yarışma sınıflamasının objektif olarak yapılabileceği bir yöntem olarak kullanılabilir.

Anahtar Kelimeler: Ampute, engelli sporcu, Paralimpik Oyunlar, yüzme, sinıflama

\section{Abstract}

The aim of this study was to examine the effect of lower and upper limb restriction on the magnitude of the propulsive force in simulated amputee front crawl swimmers. Eleven healthy male swimmers ages 15-25

\footnotetext{
* Arş. Gör., Marmara Üniversitesi, Spor Bilimleri Fakültesi, nejla.gercek@marmara.edu.tr

** Prof. Dr., Marmara Üniversitesi, Spor Bilimleri Fakültesi, ytatar@marmara.edu.tr

*** Doç. Dr. Marmara Üniversitesi, Spor Bilimleri Fakültesi, seldauzun@marmara.edu.tr
} 
years with simulated arm or leg amputation were participated in the study. Swimmers have been simulated amputees by restraining their single arms or legs. The swimmers were asked to swim at maximum speed for 10 seconds in three different conditions: normal front crawl swimming (N-FCS), arm amputee simulated front crawl swimming (ASA-FCS), leg amputee simulated front crawl swimming (LSA-FCS). Peak force, average peak force and average impulse values were examined using tethered swimming system. There were statistically significant differences in peak force, average peak force and average impulse values between N-FCS, arm amputee simulated FCS and leg amputee simulated FCS $(\mathrm{p}<0,05)$. When the arm amputee simulated FCS and leg amputee simulated FCS conditions were compared, statistically significant difference was found only in average impulse values $(\mathrm{p}<0,05)$. The negative effect of the arm or leg amputee simulation on propulsive force shows the disadvantage of amputee swimmers compared to their healthy peers in front crawl swimming. Arm amputee simulation decreased the average impulse more than leg amputee simulation. These results may support the decision of the International Paralympic Committee that single above elbow amputees and single thru knee amputees should compete in different swimming classes. Measuring swimming propulsive forces can be used as an objective method for classifying disabled athletes.

Keywords: Amputee, disabled athlete, Paralympics, swimming, the classification

\section{INTRODUCTION}

Swimming performance is determined by finishing the race distance in the shortest time. It is affected by the physiological, morphological, psychological and biomechanical characteristics of the swimmer (Dyer and Deans, 2017; Toussaint and Beek, 1992). Swimming kinematics examining stroke/kick frequency and length (Osborough, et al., 2010), and kinetics examining propulsive forces produced by extremities (Toussaint and Beek, 1992; Deschodt, Arsac and Rouard, 1999; Lecrivain et. al, 2008) are frequently focused subjects included in studies on swimming biomechanics. In these studies, it was reported that the highest percentage of the propulsive force in front crawl swimming was produced by the upper extremities. Although the force produced by the lower extremities is lower, its effect in reducing body oscillations (Gourgoulis et al., 2014) and on performing effective arm stroke (Deschodt, et al., 1999) increase its importance in swimming performance.

The increase in popularity of sports for people with disabilities has increased the number of studies on improving performance and ensuring fair races in these individuals. Swimming speed of disabled athletes has been reported 15-20\% lower than healthy swimmers (Lee, et al., 2014). In a study on amputee swimmers, it has been reported that unilateral elbow amputation decreases the propulsive force produced by $20 \%$ (Lecrivain et al., 2010). There were no study evaluating the effect of lower limb amputation on swimming performance. However, it has been found that leg kick increases swimming speed by $10 \%$ in healthy swimmers (Deschodt, et al., 1999). These studies which examine the effect of upper and lower limbs on swimming performance is often investigated during arm or leg restricted swimming (Deschodt, et al., 1999; Gourgoulis et. al., 2014). In addition, amputation was also simulated by restriction in many studies which tests situations such as walking and running (Wells, 1979; Goh, et al., 1986; Fujishita et. al., 2018). This method was frequently used because of the problems in forming homogeneous groups in the studies carried out in individuals with disabilities. 
In Paralympic games, amputee individuals compete in several categories according to the number of affected extremities and amputation level differences affecting their mobility skills. However, the effects of different amputation levels and amputation numbers on swimming performance are not clear. It is also a problem that the classification system does not make a clear distinction between adjacent classes (Oh et al., 2013). Paralympic swimming classification system is mainly based on expert opinions rather than experimental findings (IPC,2007). Therefore, the effects of different amputation levels on swimming performance may not be evaluated objectively. Using experimental methods to provide more objective assessment in classification may clarify these problems of the classification system in Paralympic swimming (Keogh, 2011).

The purpose of this study was to investigate the effect of upper or lower limb amputee simulation on the magnitude of the propulsive force produced during front crawl swimming. Since the highest percentage of propulsive force in front crawl swimming was produced by upper extremities, then it would be expected that arm amputee simulation would affect swimming performance more negatively. The hypothesis for this study was that arm restriction would reduce the propulsive force more than the leg restriction in front crawl swimming.

\section{Materials and Methods}

Participants: Eleven healthy male swimmers ages between 15-25 years were participated in the study (Table 1). The study was carried out by simulating healthy swimmers into amputees restraining their single arms or legs. Swimmers' dominant arms or dominant legs were restricted by attaching the limbs to their own bodies. This study was carried out with healthy swimmers with similar training background due to the problem of finding a sufficient number of homogeneous amputees (same amputation level with similar training background).

The swimmers who have at least four years of training age, compete in the front crawl category and have no additional problems affecting swimming performance were included in the study. Swimmers who had any physical problems that would affect the swimming performance during the measurements and who had unexpected adjustment problems during the measurements were excluded from the study. Local ethics committee approval was obtained before the study (Protocol code: 09.2017.609). The study was conducted in accordance with the Declaration of Helsinki and approval forms were received before the study.

Table 1. Characteristics of the subjects

\begin{tabular}{lll}
\hline & Mean & SD \\
\hline Age (year) & 19.55 & 2.84 \\
Height (m) & 1.79 & 0.08 \\
Weight (kg) & 77.35 & 7.80 \\
Training Age (year) & 9.55 & 3.33 \\
\hline
\end{tabular}


Measurements: Body composition measurements were made before the swimming tests. Enough time were given to each participant for warm-up on land and in water. The propulsive forces applied by swimmers during three different swimming conditions were measured using tethered swimming system.

The swimmers were asked to swim at maximum speed for 10 seconds in three different conditions; normal front crawl swimming (N-FCS) (Figure 1), arm amputee simulated (the dominant arm restricted) front crawl swimming (ASA-FCS) (Figure 2), leg amputee simulated (the dominant leg restricted) front crawl swimming (LSA-FCS) (Figure 3). Three seconds were given for the participants to settle in the water and reach the maximal effort. After three seconds, light was reflected into the water to show the start of the recording. In N-FCS condition, normal front crawl swimming was performed. In ASA-FCS condition, arm was fixed to the body by attaching from the elbow (Figure 2), and in LSA-FCS condition, lower leg was fixed on the upper leg (Figure 3). Swimming tests were carried out using tethered swimming in which the swimmers were attached to a load cell system by the non-stretch rope on the waist. After each test, 10 minutes of break were given to ensure adequate rest. Prior to each protocol, familiarization swimming trials were made to adapt the swimmer to the device and the different swimming conditions.

The propulsive forces were measured using tethered swimming system. It consists of a load cell and non-stretch rope attached to load cell. In the tethered swimming system for evaluating the propulsive force of the whole body, the non-elastic rope was fixed to the waist of the swimmer. Propulsive forces were measured using $S$ type load cell. Data was collected with an indicator at $50 \mathrm{~Hz}$ sampling rate and recorded on the computer.

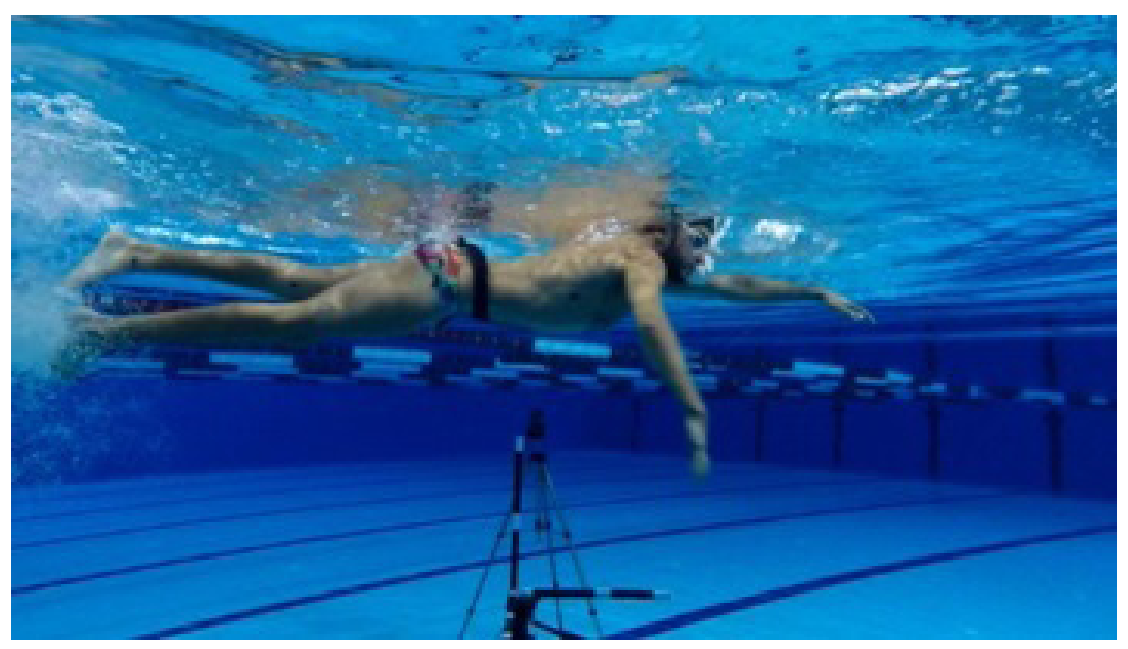

Figure 1: Normal Front Crawl Swimming 


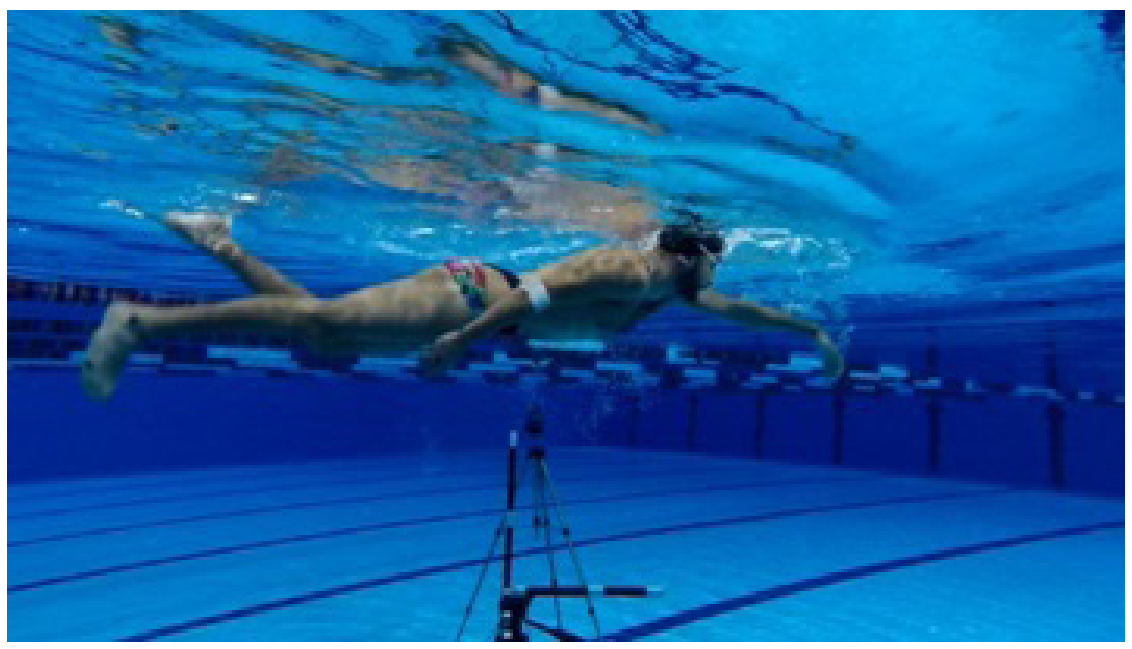

Figure 2: Arm Amputee Simulated Front Crawl Swimming

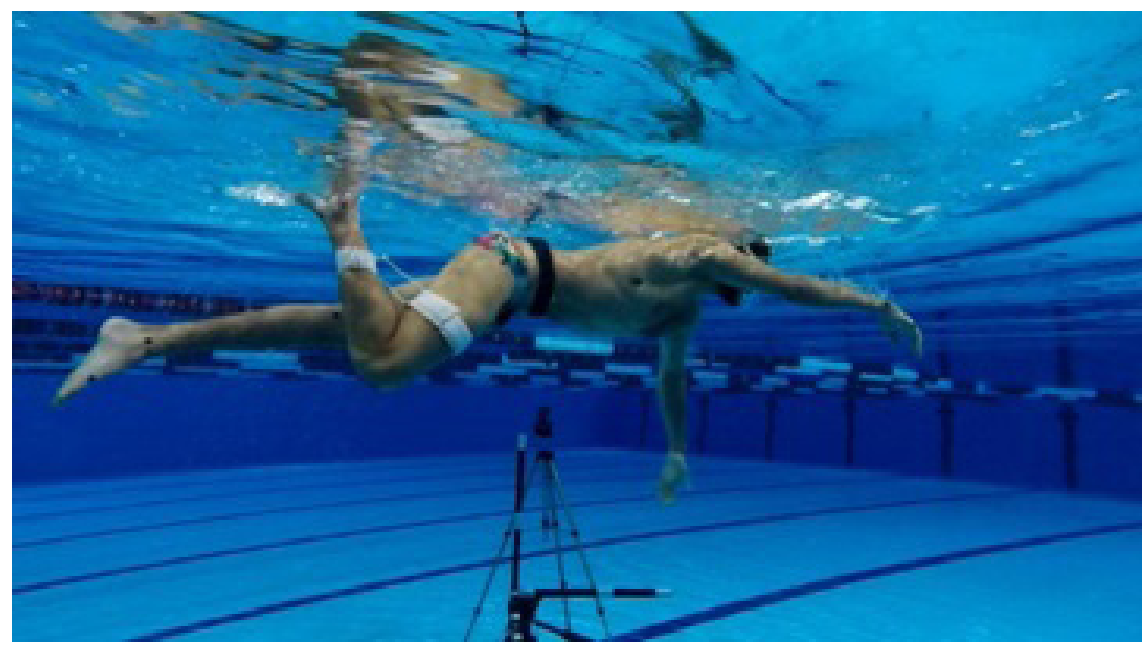

Figure 3: Leg Amputee Simulated Front Crawl Swimming

Data Processing: The data received from tethered swimming system was transferred to the computer and saved in the Excel file format. Excel files were transferred to Mat Lab and the force signals was plotted for each repetition. It was observed that athletes performed 8-9 arm strokes in ten seconds swimming tests. The first and the last three strokes were removed and the remaining three strokes in the middle were evaluated. Peak force values of each arm stroke were measured and the average peak force and impulse values were calculated. 
Data Analysis: Statistical analyses were performed using SPSS (SPSS, SPSS Inc, Chicago, IL, USA). To assess the normality of the distribution of data, skewness and kurtosis values, histogram and Q-Q plot graphs were examined and statistical analysis was done using the Shapiro Wilks test. In the results obtained, it was determined that the data were not normally distributed. For this reason, the peak force, mean peak force and impulse values obtained in all three conditions were compared with Friedman test. The differences between each two protocols were analysed using Wilcoxon test. All statistical tests were performed 2 -way and $\mathrm{p}$ value $<0.05$ was considered statistically significant. The percentage differences of the data were also calculated.

\section{Results}

Table 2. Comparison of peak force, average peak force and impulse values in three swimming conditions

\begin{tabular}{lcccc} 
& \multicolumn{3}{c}{ Swimming Conditions } \\
\cline { 2 - 4 } & N-FCS & ASA-FCS & LSA-FCS & $\begin{array}{c}\text { Three } \\
\text { Swimming } \\
\text { Condition } \\
\end{array}$ \\
& Mean (SD) & Mean (SD) & Mean (SD) & $\begin{array}{c}\text { Comparison } \\
\text { p }\end{array}$ \\
\hline Peak Force (kg) & & $20.64(4.02)$ & $23.09(3.72)$ & $.001^{*}$ \\
Average Peak Force (kg) & $26.73(4.33)$ & $19.53(3.96)$ & $20.61(2.31)$ & $.001^{*}$ \\
Impulse (kg*sec) & $24.92(4.43)$ & $9.00(1.99)$ & $10.61(1.61)$ & $.000^{*}$ \\
\hline
\end{tabular}

Note: ${ }^{*} \mathrm{p}<0.05$

According to the data evaluated during tethered swimming; peak force, average peak force and impulse values of "N-FCS", "ASA-FCS" and "LSA-FCS" tests were significantly different $(\mathrm{p}<0.05)$ (Table 2).

Table 3. Comparison of peak force, average peak force and impulse values in each two swimming conditions

\begin{tabular}{lccc}
\hline & $\begin{array}{c}\text { Peak Force } \\
\text { Mean (SD) }\end{array}$ & $\begin{array}{c}\text { Average Peak Force } \\
\text { Mean (SD) }\end{array}$ & $\begin{array}{c}\text { Impulse } \\
\text { Mean (SD) }\end{array}$ \\
\hline N-FCS vs ASA-FCS & & & \\
Normal & $26.73(4.33)$ & $24.92(4.43)$ & $13.36(2.39)$ \\
Arm Amputee Simulated & $20.64(4.02)$ & $19.53(3.96)$ & $9.00(1.99)$ \\
$\mathrm{p}$ & $.003^{*}$ & $.003^{*}$ & $.003^{*}$ \\
N-FCS vs LSA-FCS & & & \\
Normal & $26.73(4.33)$ & $24.92(4.43)$ & $13.36(2.39)$ \\
Leg Amputee Simulated & $23.09(3.72)$ & $20.61(2.31)$ & $10.61(1.61)$ \\
p & $.023^{*}$ & $.008^{*}$ & $0.004^{*}$ \\
ASA-FCS vs LSA-FCS & & & \\
Arm Amputee Simulated & $20.64(4.02)$ & $19.53(3.96)$ & $9.00(1.99)$ \\
Leg Amputee Simulated & $23.09(3.72)$ & $20.61(2.31)$ & $10.61(1.61)$ \\
p & .052 & .266 & $0.008^{*}$ \\
\hline
\end{tabular}

Note: ${ }^{*} \mathrm{p}<0.05$ 
Comparing N-FCS and ASA-FCS tests statistically significant differences were found in peak force, average peak force and impulse values $(\mathrm{p}<0.05)$ (Table 3 ). When N-FCS and ASA-FCS tests were compared statistically significant differences were found in peak force, average peak force and impulse values ( $\mathrm{p}<0.05)$ (Table 3). Between "ASA-FCS" and "LSA-FCS" tests peak force and average peak force values were not statistically different $(p<0.05)$. Between these two groups there was a statistically significant difference only in impulse values $(\mathrm{p}<0.05)$ (Table 3$)$.

Table 4. Percentage differences in peak force, average peak force and impulse values between each two swimming conditions

\begin{tabular}{lccc}
\hline & $\begin{array}{c}\text { Peak Force } \\
\text { \% difference }\end{array}$ & $\begin{array}{c}\text { Average Peak Force } \\
\text { \% difference }\end{array}$ & $\begin{array}{c}\text { Impulse } \\
\text { \% difference }\end{array}$ \\
\hline Normal - Arm Amputee Simulated & 22.18 & 21.27 & 32.08 \\
Normal - Leg Amputee Simulated & 12.26 & 15.68 & 18.96 \\
Arm Amputee Simulated - Leg Amputee Simulated & 10.05 & 5.45 & 15.20 \\
\hline
\end{tabular}

\section{Discussion}

In this study, it is found that the propulsive force generated during normal front crawl swimming was higher than the arm and leg amputee simulated swimming conditions. When the arm and leg amputee simulated swimming conditions were compared, it is found that arm restriction effects the propulsive force more than the leg restriction during front crawl swimming.

During front crawl swimming, it is determined that reduction on average peak force and impulse during arm amputee simulated swimming were higher than the leg amputee simulated swimming. This result is parallel with studies showing that the contribution of the upper extremities to the propulsive force is much more than the lower extremities (Deschodt, Arsac and Rouard, 1999; Toussaint and Beek, 1992). As the restriction of the arm will affect body rotation more than the restriction of the leg, it may have caused a further propulsive force reduction. Although lower extremities generate less propulsive force than the upper extremities, the role of leg kicks in changing the trajectory of the hand (Deschodt, et al., 1999), reducing body oscillations (Gourgoulis et al., 2014) and balancing the rotational torques (Sanders, 2015) should be considered.

Single arm amputee front crawl swimming time is $15-20 \%$ slower than healthy swimmers (Lee, et al., 2014). In this study, arm amputee simulated front crawl swimming average peak force and impulse values were also lower than the normal front crawl swimming. This is parallel with the study of Lee, Sanders and Payton. But, the difference between single elbow amputee and healthy swimmers is greater than the difference between single arm amputee simulated and normal swimming condition in this study. This difference between studies supports the results of Lecrivain et. al. (2008).

Using computational fluid dynamic model, Lecrivain et. al (2008) found that elbow amputee swimmers produce additional force with the stump. In the study of Lee, Sanders and Payton, during single elbow amputee swimming (paralympic swimming $\$ 9$ category), the stump, even if it is not the same size, may contribute to the propulsive force and rotation partially. In this study, arm amputee 
simulation (entire single arm restriction) mimics above elbow amputation (paralympic swimming S8 category). The restriction of the entire limb caused significant reduction in propulsive area and limited the shoulder rotation. These made it impossible to produce force with this extremity and resulted a more negative effect on propulsion. These results also support the paralympic classification system that above elbow and elbow disarticulation amputees competes in different swimming categories.

Deschodt, et al. (1999)'s study on healthy swimmers shows that restriction of single arm and two legs reduced the swimming performance by $4 \%$ and $10 \%$ respectively. These percentages are lower than the results of this study. However, in their study, while swimming performance was evaluated with swimming speed, in our study, it was evaluated using peak force and impulse. The difference between the arm and leg restriction methods in the aforementioned study is also a difference between the studies. In their study, during single arm restricted swimming, swimmers kept their restricted arms outstretched in front of their body, but in our study, the restricted arm was fixed to the body by attaching from the elbow. And, during two leg restriction a pull buoy was placed between the legs and lower extremities could be kept on water without effort. But, in this study, the restriction was made by fixing the lower legs of the swimmers to their own upper legs. In this condition, carrying the limb weight caused by the style of leg restriction may have resulted in the need to spend extra effort during swimming and this may have caused a greater reduction in the propulsive force. This variations between methods may have caused different results.

In addition to the limb restriction method, Swaine et. al., (2010) measured the contribution of each limb to swimming performance within the same swimming cycle in dryland. They found that contribution of the right leg and right arm to swimming performance were $16 \%$ and $29 \%$ respectively, which were relatively similar to this study. In the study of Swaine et. al., carrying the limb weight was also similar to our study. However, it is a disadvantage that the drag forces occurring during swimming cannot be taken into account in dryland measurement methods.

It has been reported that the current classification system for swimming provides a fair competition for disabled swimmers (Wu and Williams, 1999). However, in a study which assess the objectivity of the classification system by determining the relationship between passive drag and level of swimming specific impairment, it was reported that the current classification system does not always make a clear distinction between adjacent classes (Oh et. al., 2013). Due to these different research results, the need to develop a more objective classification system based on experiments has also been questioned (IPC, 2007; Keogh, 2011; Tweedy and Vanlandewijck, 2011).

In this study, arm amputee simulated swimming caused a further decrease in the propulsive force compared to leg amputee simulated swimming. This supports the current classification system, where swimmers with arm amputation compete in the S8 category, and swimmers with above knee amputee competes in the $S 9$ category where there are less severe disabled people. These results support the view that the current swimming system is successful in classification. In addition, this objective data obtained by biomechanical analysis in this study can eliminate the problems that arise 
in distinguishing between adjacent classes. Further research is needed for examining the effect of different amputation levels and especially multiple amputations on swimming performance.

\section{Limitations}

Due to the problem of finding a sufficient number of homogeneous amputees this study was carried out with healthy swimmers with similar training background. As the study is a preliminary study, power analysis has not been performed.

\section{Acknowledgements}

This study is supported by Marmara University, Sports Science and Athletes Health Application and Research Centre and Physical Disability Foundation (FEV). The equipments used in this research supplied by the Marmara University as part of a scientific research project (Project Code: SAG-CDRP-110.618.0310).

\section{References}

Deschodt, V. J., Arsac, L. M., \& Rouard, A. H. (1999). Relative contribution of arms and legs in humans to propulsion in 25-m sprint front-crawl swimming. European journal of applied physiology and occupational physiology, 80(3), 192-199.

Dyer, B. T., \& Deans, S. A. (2017). Swimming with limb absence: A systematic review. Journal of Rehabilitation and Assistive Technologies Egineering, (4), 1-10.

Fujishita, H., Urabe, Y., Maeda, N., Komiya, M., Sakai, S., Hirata, K., ... \& Kimura, H. (2018). Biomechanics of single-leg running using lofstrand crutches in amputee soccer. Journal of physical therapy science, 30(12), 1483-1487.

Goh, J. C. H., Toh, S. L., \& Bose, K. (1986). Biomechanical study on axillary crutches during single-leg swingthrough gait. Prosthetics and Orthotics International, 10(2), 89-95.

Gourgoulis, V., Boli, A., Aggeloussis, N., Toubekis, A., Antoniou, P., Kasimatis, P., ... \& Mavromatis, G. (2014). The effect of leg kick on sprint front crawl swimming. Journal of Sports Sciences, 32(3), 278-289.

International Paralympic Committee. (2007). IPC classification code and international standards.

Keogh, J. W. (2011). Paralympic sport: an emerging area for research and consultancy in sports biomechanics. Sports Biomechanics, 10(3), 234-253.

Lecrivain, G., Payton, C., Slaouti, A., \& Kennedy, I. (2010). Effect of body roll amplitude and arm rotation speed on propulsion of arm amputee swimmers. Journal of biomechanics, 43(6), 1111-1117.

Lecrivain, G., Slaouti, A., Payton, C., \& Kennedy, I. (2008). Using reverse engineering and computational fluid dynamics to investigate a lower arm amputee swimmer's performance. Journal of Biomechanics, 41(13), 2855-2859.

Lee, C. J., Sanders, R. H., \& Payton, C. J. (2014). Changes in force production and stroke parameters of trained able-bodied and unilateral arm-amputee female swimmers during a $30 \mathrm{~s}$ tethered front-crawl swim. Journal of sports sciences, 32(18), 1704-1711. 
Oh, Y. T., Burkett, B., Osborough, C., Formosa, D., \& Payton, C. (2013). London 2012 Paralympic swimming: passive drag and the classification system. British journal of sports medicine, 47(13), 838-843.

Osborough, C. D., Payton, C. J., \& Daly, D. J. (2010). Influence of swimming speed on inter-arm coordination in competitive unilateral arm amputee front crawl swimmers. Human movement science, 29(6), 921-931.

Sanders, R. H. (2013). How do asymmetries affect swimming performance? Journal of Swimming Research, 21(1).

Swaine, I. L., Hunter, A. M., Carlton, K. J., Wiles, J. D., \& Coleman, D. (2010). Reproducibility oflimb power outputs and cardiopulmonary responses to exercise using a novel swimming training machine. International journal of sports medicine, 31(12), 854-859.

Toussaint, H. M., \& Beek, P. J. (1992). Biomechanics of competitive front crawl swimming. Sports medicine, 13(1), 8-24.

Tweedy, S. M., \& Vanlandewijck, Y. C. (2011). International Paralympic Committee position stand—background and scientific principles of classification in Paralympic sport. British journal of sports medicine, 45(4), 259-269.

Wells, R. P. (1979). The kinematics and energy variations of swing-through crutch gait. Journal of biomechanics, 12(8), 579-585.

Wu, S. K., \& Williams, T. (1999). Paralympic swimming performance, impairment, and the functional classification system. Adapted Physical Activity Quarterly, 16(3), 251-270. 